\title{
MENGEMBANGKAN KETERAMPILAN BERPIKIR KESEJARAHAN SISWA DALAM PEMBELAJARAN SEJARAH MELALUI PENGGUNAAN BIOGRAFI TOKOH R.A LASMININGRAT SEBAGAI SUMBER PEMBELAJARAN SEJARAH
}

\author{
Purnama Nurdiana Purnaman, Prodi Pendidikan Sejarah, SPs, UPI, \\ e-mail : purnama_pnp@yahoo.com
}

\begin{abstract}
ABSTRAK
Penelitian ini berjudul Mengembangkan Keterampilan Berpikir Kesejarahan Siswa Dalam Pembelajaran Sejarah Melalui Penggunaan Biografi Tokoh R.A Lasminingrat Sebagai Sumber Pembelajaran Sejarah (Penelitian Tindakan Kelas Pada Kelas XI IPS 2 di MAN 2 Garut). Penelitian ini mendasarkan pada perbaikan proses pembelajaran sejarah di Kelas XI IPS 2 MAN 2 Garut. Proses tersebut yaitu melihat ketercapaian keterampilan berpikir kesejarahan siswa melalui penggunaan materi biografi R.A Lasminingrat. Hasil penelitian menunjukan bahwa penerapan keterampilan berpikir kesejarahan meningkat. Hal ini dapat terlihat dari nilai task yang diberikan kepada siswa. Adapun kendala utama dalam penerapan keterampilan berpikir kesejarahan yaitu tingkat keterampilan siswa dalam membaca narasi sejarah.
\end{abstract}

Kata kunci : Keterampilan berpikir kesejarahan, biografi R.A Lasminingrat.

\section{PENDAHULUAN}

Pembelajaran keterampilan berpikir kesejarahan belum dilakukan secara intensif oleh guru mata pelajaran sejarah. Sebagai contoh, guru di Madrasah Aliyah Negeri 2 Garut masih belum meningkatkan kompetensi keterampilan berpikir kesejarahan kepada siswa secara menyeluruh. Walaupun, materi kelas $\mathrm{X}$ sudah memperkenalkan beberapa bagian tentang keterampilan berpikir kesejarahan. Pada saat penelitian pendahuluan, guru mata pelajaran sejarah ini lebih banyak menggunakan pendekatan ekspositori dengan strategi ceramah, tanya jawab, dan pengerjaan lembar kerja siswa (LKS). Pendekatan tersebut tentunya kurang memuaskan dalam pembelajaran keterampilan kesejarahan yang menjadi dasar bagi siswa ketika dihadapkan pada narasi sejarah.

Berdasarkan diskusi dan pengalaman penulis dengan observer selama mengajar, pembelajaran sejarah oleh guru jarang sekali yang menggunakan tokoh lokal atau sejarah lokal dalam materi pembelajarannya. Mereka sebagian besar menggunakan buku paket atau lembar kerja siswa yang digunakan untuk bahan materi pembelajaran. Dampak dari penggunaan materi tersebut, guru terjebak pada apa yang dikatakan oleh Parrington dalam bukunya The Idea of an Historical Education (1980) dengan pernyataan guru acapkali mendominasikan pengajaran hapalan dan menekankan "chalk and talk" dengan menekankan memorizing sehingga mengabaikan kemampuan intelektual yang lebih tinggi (Mulyana \& Gunawan, 2007:1-9).

Lebih lanjut, fakta pembelajaran yang selama ini dilakukan yaitu siswa hanya menghapal untuk meningkatkan prestasi belajar sejarah. Sebagian besar siswa kurang tertarik terhadap mata pelajaran sejarah. Guru lebih menggunakan metode pengajaran konvensional dan mengutamakan penggunaan metode ekspositori untuk mengejar penyampaian konten materi. Guru 
menggunakan authentic assessment sebagai dasar alat penilaian pada hasil belajar. Guru masih terfokus pada materi buku paket, sehingga sejarah lokal tidak terangkat, dan pengalaman belajar keterampilan sejarah bagi siswa terabaikan. Keadaan ini sesuai dengan pendapat Wasserman (dalam Murni, 2006:73) bahwa :

teacher's competence is being assessed by pupil performance on such measures. Teaching for thinking is fine, in theory, and we want it. But in the real world, where pupil's learning is measured, not by their competence as thinkers, but their ability to recall what has been heard and read.

Guru masih mempersiapkan siswa untuk mengerjakan tes atau istilah lain teaching to the test. Akibatnya, guru melihat kemampuan hasil belajar sejarah siswa berdasarkan tes belajar siswa yang dicapainya. Sementara itu, hasil belajar berdasarkan keterampilan berpikir kesejarahan terabaikan. Dengan demikian, hasil belajar siswa diinterpretasikan yaitu siswa akan berhasil kalau mereka mampu mengingat apa yang dia ingat dan dia baca. Kondisi ini hampir berlaku pada setiap kelas, salah satunya yaitu kelas XI IPS 2.

Fakta lain yaitu saratnya materi dan terfokusnya pada materi buku paket yang diajarkan oleh guru berdampak tidak terangkatnya sejarah lokal yang ada di sekitar siswa. Padahal, siswa tidak terlepas dari identitas komunitasnya di samping mereka harus memahami sejarah nasional. Seperti yang diungkapkan oleh Hasan (2012, hlm. 27) bahwa materi sejarah nasional sebagai "collective memory" harus dikembangkan oleh pendidikan sejarah. Identitas diri sebagai bangsa dikembangkan melalui pendidikan nasional dengan materi yang diterima pada tingkat nasional pun terlalu didominasi oleh materi sejarah yang terjadi di pulau Jawa. Tetapi, orang tidak mungkin melepaskan dirinya dari identitas komunitas terdekatnya.

Fakta ketidaktahuan tentang tokoh R.A Lasminingrat sebagai tokoh intelektual tidak muncul di kalangan siswa. Walaupun situssitus tokoh tersebut berdekatan dengan sekolah siswa (di sekitar alun-alun Garut). Mereka tidak tahu apa peran dari tokoh R.A Lasminingrat. Padahal, ada dua penulis (Nina Herlina Lubis (2009) dan Dedy Effendie (2010) yang menyatakan tokoh perempuan tersebut sangat berperan di Kabupaten Garut sebagai sastrawati dan pendidik. Kiprah peran intelektualnya jauh berpengaruh sebelum R.A Kartini ataupun R. Dewi Sartika. Dengan demikian, nilai-nilai yang terkandung dalam perjalanan tokoh tersebut belum menjadi teladan bagi siswa.

Penggunaan tokoh sebagai pendekatan biografi diharapkan memberikan solusi kebermaknaan dalam pembelajaran sejarah. Hariyono (1995, hlm. 196) mengungkapkan tujuan belajar sejarah yaitu untuk mengerti dan mampu berpikir secara historis. Kemudian, belajar sejarah adalah berusaha menguasai kemampuan berpikir secara imajinatif, untuk mengorganisir informasi, dan menggunakan pelbagai fakta dalam rangka menemukan dan memahami ide yang signifikan. Untuk itu, kajian bersifat kontekstual dan secara simultan terkait dengan substansi bidang sejarah akan banyak membantu.

Kartodirdjo (1993:76) menyatakan biografi yang ditulis secara baik sangat mampu membangkitkan inspirasi kepada pembaca dan dipandang memiliki fungsi yang penting dalam pendidikan. Dengan biografi, pembaca dapat menyelami dan mendalami kepribadian seseorang dimulai dari latar belakang, sosio kultural dan proses pendi- 
dikannya. Dengan menyelami biografi tersebut, pembaca akan muncul rasa empati.

KTSP memberikan peluang kepada guru sejarah untuk mengembangkan sejarah di lingkungan sekitarnya sehingga membangun memory collective dari tingkat lokal ke nasional. Memory collective tingkat lokal dapat memberikan motivasi dan rasa ingin tahu terhadap siswa untuk lebih mengetahui sejarah lingkungannya. Namun, kenyataannya sebagian besar guru memiliki salah tafsir terhadap KTSP. Sebagian besar guru menganggap perubahan kurikulum hanya sebagai perubahan nama saja. Dampak dari anggapan tersebut, mereka masih tetap melakukan pembelajaran yang konvensional. Padahal, kalau guru berpikir dan bertindak kreatif, banyak sumber-sumber belajar sejarah di sekitar lingkungan siswa untuk dikembangkan. Sumber-sumber belajar tersebut sangat bermanfaat untuk mengembangkan keterampilan belajar kesejarahan (historical thinking) yang selama ini masih kurang dikembangkan.

Salah satu materi sejarah lokal yang dapat diangkat dalam pembelajaran sejarah untuk mengembangkan keterampilan berpikir kesejarahan yaitu biografi seorang tokoh. Pada penelitian ini mengangkat tokoh R.A Lasminingrat yang sezaman dengan masa kolonial Belanda juga munculnya perkembangan pendidikan di Hindia Belanda pada umumnya.

Pengambilan peran R.A Lasminingrat akan memberikan motivasi terhadap siswa dengan nilai-nilai yang terkandung pada perjalanan beliau. Secara kronologis, R.A Lasminingrat telah berperan terhadap pendidikan yaitu menerjemahkan buku berbahasa Belanda ke dalam Bahasa Sunda untuk tujuan pendidikan kaum Bumiputra jauh sebelum lahirnya R.A Kartini. Hal ini dapat dilihat dari sepucuk surat KF Holle kepada Gubernur Jenderal tertanggal 20 Agustus 1873 (dalam Effendie, 2011:70)

...Salah seorang anak perempuan Hoofdpanghulu yang tinggal bersama keluarga Levyssohn di Sumedang untuk waktu yang lama sebelum dia menikah, tidak hanya berbicara bahasa Belanda dan sudah terbiasa dengan berbagai hal yang bagus seperti disiplin dan kebersihan, tetapi sekarang juga menerjemahkan buku berbahasa Belanda ke dalam bahasa Sunda untuk tujuan pendidikan kaum Bumiputra...

Dilihat dari kiriman surat tersebut, R.A Lasminingrat sudah berperan pada bidang pendidikan melalui penerjemahan sebelum tahun 1873 tepatnya tahun 1871 (Effendie, 2011:74-75), sedangkan R.A Kartini lahir pada tahun 1879 (Soebadio, 1979:9) dan R.A. Dewi Sartika Lahir pada tahun 1884. Maka, ada selisih 8 tahun antara peran R.A Lasminingrat dengan kelahiran R.A Kartini apalagi dengan R.A Dewi Sartika. Dengan demikian, Effendi (2011) berpendapat bahwa R.A Lasminingrat sebagai perempuan intelektual pertama di Indonesia.

Terlepas dari pendapat perempuan intelektual pertama di Indonesia, dalam pembelajaran sejarah R.A Lasminingrat memberikan nilai-nilai kepada siswa yang dimunculkan dari biografi R.A Lasminingrat tersebut. Pertama, kebangkitan emansipasi wanita sudah berusaha dijalankan oleh ayahnya yaitu R. H. Muhammad Moesa dengan menyekolahkan R.A Lasminingrat bersama laki-laki yaitu sekitar tahun 1860an. Kedua, R.A Lasminingrat mampu mengeksiskan diri melalui karangankarangan yang dibuatnya berupa saduran dan lain-lain. Ketiga, ada peran dalam pendidikan terutama mendorong R.Dewi Sartika untuk mendirikan Sakola Isteri. 
Peran R.A Lasminingrat sebagai perempuan intelektual pertama dan pendorong pendidikan di Kabupaten Garut seharusnya dibelajarkan kepada siswa supaya mengenal pelopor pendidikan perempuan. Pembelajaran inipun dapat mengambil nilai-nilai sejarah oleh siswa. Metode pembelajaran tersebut yaitu melalui tulisan-tulisan biografi beliau baik artikel maupun buku. Namun, artikel dan buku seharusnya dikritisi oleh siswa. Siswa seharusnya dibelajarkan mengenai keterampilan berpikir kesejarahan sebagai dasar dalam pengambilan keputusan nilai-nilai yang terkandung dalam narasi sejarah sehingga siswa akan menilai sendiri sejarah lokal dan sejarah nasionalnya.

Hasan (2012:57) menyatakan bahwa pendidikan sejarah bukan pengajaran biografi tetapi sebaliknya pendidikan sejarah tidak harus menutup diri menggunakan pendekatan pengajaran biografi. Dengan demikian, pengajaran biografi merupakan salah satu pendekatan pengajaran yang potensial, membuat pelajaran sejarah menjadi "exciting as life itself" (Curtis, 2009) sehingga memberikan kesempatan belajar sejarah lebih manusiawi.

Pada kurikulum 2013, Sejarah lokal semakin terakomodir. Dengan demikian, kedekatan siswa dengan sejarah diri dan lingkungannya semakin terjembatani. Peluang adanya pengangkatan materi sejarah lokal dalam proses belajar mengajar di sekolah harus pula ditanggapi oleh guru sejarah yang kreatif dan inovatif. Kreatif dan inovatif diartikan mengembangkan metodemetode mengajar yang disesuaikan dengan kompleksitias materi, intakes siswa, dan daya dukung proses belajar mengajar.

Ada pemeo yang mengemukakan tentang "act lokal, think global". Hal ini sejalan dengan pembelajaran sejarah lokal untuk menjadikan siswa sebagai pelaku sejarah di lokalitasnya. Namun, mereka tetap diajarkan berpikir mengedepan dan memperhatikan keadaan global. Dalam hal ini, sejarah lokal dipandang memiliki kekayaan nilai-nilai yang dapat dijadikan pijakan oleh siswa dalam bertindak tetapi tetap memiliki pemikiran untuk kehidupan global.

Melalui materi sejarah lokal, siswa merasa ada kedekatan emosional terhadap lingkungannya sehingga nilai genealogis, kesadaran sejarah, dan kolektif memories akan terbangun dimulai dari lokalitas menuju nasional. Hal ini sejalan dengan pemikiran Hasan (2012:122) bahwa "posisi materi sejarah lokal dianggap penting karena pendidikan harus dimulai dari lingkungan terdekat dan peserta didik harus menjadi dirinya sebagai anggota masyarakat terdekat". Lingkungan terdekat tersebut yaitu mengenai sejarah keluarga, desa, kelurahan, kecamatan dan seterusnya menjadi penting karena ia hidup dilingkungan tersebut sampai kepada sejarah bangsa dimana ia adalah sebagai warganya.

Berdasarkan latar belakang masalah di atas, mulai dari kurikulum KTSP, Biografi tokoh R.A Lasminingrat merupakan sumber belajar sejarah lokal yang dapat mengembangkan keterampilan berpikir kesejarahan. Selain itu, sesuai dengan prinsip-prinsip pengembangan KTSP dengan pemusatan pada kondisi potensi siswa dan lingkungan, dapat menyeimbangkan kepentingan nasional dan daerah. Penggunaan biografi lokal yang belum tergali secara mendalam merupakan kajian yang menarik untuk dijadikan bahan materi pembelajaran sejarah di Madrasah Aliyah Negeri 2 Garut. Melalui penggunaan biografi, penelitian ini berharap dapat mengembangkan kemampuan keterampilan berpikir kesejarahan siswa dalam 
pembelajaran sejarah. Maka, penulis tertarik untuk menulis pengembangan keterampilan berpikir kesejarahan siswa dengan rumusan masalah yaitu bagaimanakah implementasi pembelajaran biografi tokoh lokal: R.A Lasminingrat dapat mengembangkan keterampilan berpikir kesejarahan kepada peserta didik di kelas XI IPS 2 MAN 2 Garut.

\section{METODE PENELITIAN}

Penelitian ini merupakan salah satu upaya dalam memperbaiki permasalahan dalam pembelajaran sejarah di kelas XI IPS 2 MAN 2 Garut sebagai inovasi mewujudkan pengembangan keterampilan berpikir kesejarahan siswa. Sehingga, metode penelitian yang digunakan yaitu Penelitian Tindakan Kelas (PTK). Adapun penelitian ini melalui dua siklus. Sebagai indikator ketercapaian keterampilan berpikir kesejarahan, peneliti mengacu kepada indikator dari Nash (Ma'mur, 2008:201), Kamsori (2006) dan merujuk dari http://www.nchs.ucla.edu/ dengan 5 standar yaitu : 1) Chronological thinking (berpikir kronologis); 2) Historical comprehension (pemahaman sejarah); 3) Historical analysis and interpretation (menganalisis dan menginterpretasi kesejarahan); 4) Historical research capabilities (kemampuan penelitian kesejarahan); 5) Historical issues-analysis and decision making (menganaisis isyu dan membuat keputusan kesejarahan).

Adapun perbaikan siklus I menekankan pada tiga indikator keterampilan berpikir kesejarahan yaitu chronological thinking, historical comprehenship dan historical research capabilities. Untuk melihat perkembangan keterampilan berpikir kesejarahan, pada siklus satu dilakukan tiga tindakan. Pada siklus dua, indikator yang akan dicapai yaitu historical analysis and interpretation dan historical issues-analysis and making decision. Pada siklus dua dilakukan dengan tiga kali tindakan. Pada penelitian ini menggunakan model penelitian tindakan kelas yang dilakukan dalam penelitian ini menggunakan model spiral dari Kemmis dan Mc Taggart. Adapun desain yang digunakan melalui tahapan perencanaan (plan), pelaksanaan (act), observasi (observe) dan refelkesi (reflect) (Wiriaatmadja, 2012:70). Teknik pengumpulan data meliputi observasi, catatan lapangan, wawancara, kuesioner, foto-foto, dan dokumen.

\section{HASIL DAN PEMBAHASAN}

Penelitian ini bertujuan untuk memperbaiki proses belajar mengajar di kelas XI IPS 2 MAN 2 Garut mengenai keterampilan berpikir kesejarahan siswa. Adapun sebelum melakukan tindakan, guru peneliti terlebih dahulu melakukan tahap orientasi untuk melihat karakteristik siswa. Setelah mendapatkan data, kemudian guru peneliti bersama guru mitra melakukan perencaan untuk tahap tindakan kelas.

\section{Desain Pembelajaran Keterampilan Berpikir Kesejarahan}

Sebelum kepada tindakan, guru mitra dan guru peneliti melakukan refleksi dari hasil orientasi. Hasil refleksi tersebut yaitu membuat desain pembelajaran. Desain pembelajaran tersebut dimasukan kedalam RPP. Pada RPP meliputi komponen yang menjadi focus utama yaitu siswa, Standar Kompetensi dan Kompetensi Dasar (SK/KD), tujuan pembelajaran, materi pembelajaran, kegiatan pembelajaran, sumber/media dan evaluasi pembelajaran.

SK/KD yang digunakan dalam pelaksanaan PTK ini yaitu mengacu kepada Kurikulum Tingkat Satuan Pendidikan 
(KTSP). Tujuan pembelajaran dalam PTK ini disesuaikan dengan tujuan pembelajaran yang ada di KTSP dan menentukan sendiri tujuan pembelajaran disesuaikan dengan penelitian seperti membuat kronologis waktu masa kehidupan R.A Lasminingrat, Menyandingkan peristiwa nasional yang sezaman dengan kehidupan R.A Lasminingrat melalui garis waktu kronologis.

Materi pembelajaran merupakan pengembangan yang diambil dari artikel-artikel yang berkaitan dengan biografi tokoh R.A Lasminingrat. Pada materi ini, guru mitra dan guru peneliti menyepakati artikel dari Affandi Hutari, Purnama Nurdiana Purnaman S.Pd dan Nina Herlina Lubis. Kemudian, kegiatan pembelajaran meliputi tiga kegiatan yaitu kegiatan awal, inti dan penutup. Secara umum kegiatan pembelajaran dilaksanakan dengan mengembangkan keterampilan berpikir kesejarahan dengan menggunakan task sebagai alatnya.

Metode pembelajaran yang dilakukan oleh guru peneliti yaitu dengan ceramah dan tanya jawab terlebih dahulu sebagai bahan membekali siswa tentang pengetahuan rangkaian keterampilan berpikir kesejarahan. Metode yang dilakukan peneliti disepakati dengan menyesuailkan pada kondisi lapangan. Namun, model dan strategi yang digunakan tetap konsisten yaitu model pembelajaran Text book study. Text book study yaitu peserta didik dapat menemukan keterangan khusus dari buku teks dan dapat selalu mengingat perbedaan batasan pengertian antara satu dengan yang lain, serta dapat mengamati peristiwa berdasarkan informasi atau gambar di dalam buku teks. Buku teks memiliki peran dalam pengembangan kreativitas pegajar dan siswa agar mampu mendalami dan memiliki keterampilan sejarah.
Strategi pembelajaran dalam PTK ini yaitu menggunakan strategi pembelajaran langsung (directive) yaitu Pertama, introduce yaitu mengenalkan topik kajian yang dilakukan baik dengan penulisan topik didepan (papan tulis) ataupun secara lisan. Kedua, explain yaitu menjelaskan beberapa kunci prosedur dan petunjuk praktis pencapaian serta penguasaan materi. Ketiga, using sample yaitu guru dituntut memberikan contoh-contoh yang akurat sesuai dengan topik kajian. Keempat,apply the skill as modeled by teacher yaitu pengujian daya serap siswa atas hasil belajarnya atau kemampuan hasil belajar selama proses pembelajaran dengan titik berat apa yang dicontohkan oleh guru yaitu melalui penugasan langsung (task). Kelima, reflection yaitu merefleksikan keberhasilan pencapaian tujuan pembelajaran secara menyeluruh. Pada awal pembelajaran menggunakan metode ceramah terlebih dahulu, karena materi pembelajaran masih asing serta pembelajaran task pun masih asing bagi siswa. Namun, guru tidak mengabaikan Kompetensi Dasar yang menjadi dasar pembelajaran, hanya saja materinya berisi tentang sejarah lokal yaitu biografi tokoh lokal R.A Lasminingrat. Sehingga, beberapa keterampilan berpikir kesejarahan akan tercapai.

Komponen evaluasi yaitu disesuaikan dengan tujuan penelitian dan pengembangan pembelajaran keterampilan berpikir kesejarahan. Pada awal sebelum PTK, evaluasi yang digunakan yaitu bentuk evaluasi konvensional yaitu soal-soal yang digunakan pada buku teks atau LKS. Pada PTK ini, guru mitra dan guru peneliti merancang evaluasi untuk mengukur ketercapaian indikator keterampilan berpikir kesejarahan. Penggunaan evaluasi tersebut yaitu melalui 
asesmen alternative dengan penggunaan task (penugasan) dan penilaian dengan rubrik.

Task ini dipergunakan untuk melihat perkembangan keterampilan berpikir kesejarahan terhadap suatu narasi sejarah. Task pada siklus I pertanyaannya sama, namun bahan materi atau artikelnya berbeda-beda seperti tindakan satu yaitu menggunakan artikel Affandi Hutari. Tindakan kedua yang digunakan dari tulisan Purnama Nurdiana Purnaman dan Tindakan ketiga menggunakan tulisan Nina Herlina Lubis. Pada siklus I merupakan tindakan untuk melihat perkembangan keterampilan berpikir kesejarahan dengan 3 indikator yaitu kemampuan chronological thinking, historical comprehenship, dan historical research capabilities. Pada siklus II, evaluasi sama yaitu menggunakan task, dengan alat artikel yang sama tetapi indikator yang ingin dicapai berbeda yaitu kemampuan historical analysis and interpretation, dan historical issuesanalysis and decision making.

\section{Implementasi Pengembangan Keteram- pilan Berpikir Kesejarahan Melalui Penggunaan Biografi R.A Lasminingrat}

\section{Analisis Siklus 1}

Siklus 1 dilaksanakan untuk melihat pengembangan tiga keterampilan berpikir kesejarahan, yaitu kemampuan chronological thinking, historical comprehenship, dan historical research capabilities. Berdasarkan observasi, catatan lapangan, dan hasil penilaian berupa task menunjukan perkembangan dari tiap tindakan yaitu tindakan 1, 2, dan 3. Tindakan ke-1 dilakukan dengan metode ceramah, hal ini efektif untuk pembelajaran hal yang baru, karena siswa perlu cara-cara bagaimana keterampilan berpikir kesejarahan tersebut. Pengambilan metode ceramah dengan model text book study dan strategi direct teaching memudahkan siswa dalam memahami apa yang seharusnya dicapai. Hal ini cocok untuk pembelajaran keterampilan berpikir kesejarahan. Penayangan situs-situs, fotofoto tentang Lasminingrat menarik perhatian siswa untuk lebih peka terhadap keadaan lokalitasnya, dan ini terbukti mereka tidak tahu tentang sosok R.A Lasminingrat.

Pada tindakan kedua, siswa masih perlu bimbingan dalam berpikir kesejarahan. Kondisi ini dapat terlihat dengan penempatan waktu yang salah. Guru sudah berusaha menyederhanakan penjelasan mengenai kronologis waktu. Maka, dengan temuan ini, siswa perlu adanya peningkatan dalam keterampilan dasar ini. Guru perlu pembelajaran yang lebih lanjut tentang keterampilan berpikir kesejarahan ini. Penemuan selanjutnya yaitu siswa mulai kebosanan dengan membaca narasi sejarah yang diberikan oleh guru. Namun, peneliti menginterpretasikan bahwa sebuah keterampilan harus dilakukan berulang-ulang sampai memiliki kelancaran dalam keterampilan tersebut. Seperti yang dikemukakan oleh Surya (2004:11-12) bahwa pembelajaran melalui latihan yaitu aspek perilaku yang berubah adalah perubahan dalam bentuk skill atau keterampilan. Pembelajaran akan lebih berhasil apabila disertai dengan latihan-latihan yang teratur dan terarah. Dengan demikian, keterampilan berpikir kesejarahan masih tetap dengan model text book study sebagai latihan membaca suatu narasi sejarah dan latihan tersebut perlu dipaksakan. Maka, guru hanya perlu memperbaiki metode mengajarnya.

Pada tindakan ke-3, siswa sudah mulai terbiasa dengan tiga keterampilan berpikir kesejarahan ini. Apalagi, guru memberikan kesempatan untuk berdiskusi dalam sebuah 
kelompok kecil. Penemuan ini ditunjukan dari hasil task siswa yang diberikan oleh guru. Secara keseluruhan pada tindakan ke-3 ini menunjukan perubahan dari tindakan sebelumnya. Peneliti beranggapan bahwa data yang dibutuhkan untuk melihat tiga keterampilan berpikir kesejarahan sudah cukup. Desain model dan strategi pembelajaran text book study melalui artikel atau narasi sejarah memiliki keefektifan bagi siswa dalam perkembangan keterampilan berpikir kesejarahan.

\section{Analisis Siklus II}

Siklus II ini ditujukan untuk melihat perkembangan dua keterampilan berpikir kesejarahan yaitu kemampuan historical analysis and interpretation dan historical issues-analysis and decision making. Pada siklus ini, peneliti melakukan tiga kali tindakan untuk melihat saturasi data.

Berdasarkan hasil observasi, catatan lapangan, dan hasil task yang dikerjakan oleh siswa pada tindakan ke-4 belum menunjukan keterampilannya. Kondisi ini menurut interpretasi peneliti karena bersifat baru. Temuan dalam tindakan 4 ini yaitu materi yang bersifat keterampilan kurang efektif melalui diskusi. Maka, pada tindakan ke-5, guru pada awal pembelajaran melakukan ceramah selama 10 menit untuk menjelaskan cara-cara yang diharapkan oleh guru. Adapun langkah ini diambil untuk mengefektifkan task yang baru.

Langkah- langkah yang diambil oleh guru mengadopsi pada strategi pembelajaran langsung (directive) yaitu; Pertama, introduce yaitu mengenalkan topik kajian yang dilakukan baik dengan penulisan topik didepan (papan tulis) ataupun secara lisan. Kedua, explain yaitu menjelaskan beberapa kunci prosedur dan petunjuk praktis pencapaian serta penguasaan materi. Ketiga, using sample yaitu guru dituntut memberikan contoh-contoh akurat sesuai topik kajian. Keempat, apply the skill as modeled by teacher yaitu pengujian daya serap siswa atas hasil belajarnya atau kemampuan hasil belajar selama proses pembelajaran dengan titik berat apa yang dicontohkan oleh guru. Kelima, reflection yaitu merefleksikan keberhasilan pencapaian tujuan pembelajaran secara menyeluruh. Sebagai indikator keberhasilan belajar dapat dilihat dari keterampilan mengemukakan pendapat jawaban baik lisan maupun tulisan (Beyern dalam Isjoni, 2007:110).

Setelah itu, guru mencoba dilakukan diskusi kelompok melalui jigsaw. Tindakan ini memiliki kelebihan yaitu siswa berusaha mengkomunikasikan hasil kajian dari kelompok ahlinya kepada anggota kelompok barunya sehingga, nilai task yang dikerjakan siswa mulai muncul dan mengarah kepada kebaikan. Namun, peneliti belum merasa yakin dengan hasil tersebut, sehingga perlu adanya tindakan lagi. Adapun model dan strategi pembelajaran pada tindakan ke-6 masih tetap menggunakan tindakan-tindakan sebelumnya. Namun, metode pembelajaran yang dipilih yaitu tidak berbentuk kelompok, tetapi siswa duduk secara konvensional. Metode ini untuk memudahkan guru melihat hasil pemahaman siswa dalam mengembangkan keterampilan berpikir kesejarahan melalui task.

Pada tindakan ke-6 terlihat siswa sudah mengalami perkembangan terlihat dari pengisian task yang dikerjakan walaupun dilakukan oleh mereka sendiri atau individu.

\section{Kendala-kendala yang ditemukan dalam pembelajaran}

Pembelajaran keterampilan berpikir kesejarahan melalui biografi tokoh lokal mewadahi tuntutan siswa dalam kehidupan 
sehari-hari yaitu siswa dihadapkan pada narasi-narasi sejarah yang banyak. Potensi dan tujuan pembelajaran sejarahpun terwadahi seperti pemahaman terhadap materi sejarah, penghayatan terhadap sejarah, minat terhadap sejarah, sikap kebangsaan, pandangan tentang perubahan, pandangan tentang kontinuitas, pandangan tentang guna sejarah, dan keterampilan berpikir kesejarahan (Isjoni, 2007:91).

Pelaksanaan PTK dalam mengembangkan keterampilan berpikir kesejarahan melalui biografi tokoh R.A Lasminingrat memang berjalan sesuai dengan perencanaan yang dibuat oleh guru secara kolaborasi. Namun, kendala-kendalapun muncul dalam penerapan pengembangan keterampilan berpikir kesejarahan ini. Berbagai kendala tersebut diidentifikasi sebagai berikut.

\section{1) Kompleksitas dan Triabilitas}

Pengembangan keterampilan berpikir kesejarahan merupakan inovasi di lingkungan MAN 2 Garut, sehingga penolakan atau sikap keragu-raguan muncul. Sebagai contoh yaitu guru mitra tidak bersedia sebagai pengajar untuk penerapan keterampilan berpikir kesejarahan ini. Sehingga apa yang dikatakan Rogers (1971:230-231) bahwa inovasi tidak lepas dari penolakan jika tingkat komplesitas/tingkat kesulitan yang dihadapi. Sebagai contoh yaitu sikap siswa yang mulai menurun motivasinya ketika dilakukan penugasan membaca literatur. Sedangkan triabilitas, yaitu apakah inovasi tersebut dapat di coba atau tidak.

Berdasarkan pada pendapat Rogers, pelaksanaan PTK ini mengalami kendala terutama tingkat kesulitan dalam memahami pembelajaran keterampilan berpikir kesejarahan. Namun, ketika di coba melalui PTK ini, inovasi ini berjalan dengan baik kalau terus berulang-ulang sehingga guru dan siswa memahami arah dan tujuan keterampilan berpikir kesejarahan melalui biografi R.A Lasminingrat. Sedangkan uji coba pengembangan keterampilan berpikir kesejarahan ini memerlukan waktu yang lama terkait dengan kompleksitasnya. Dalam hal ini, guru peneliti dan guru mitra memiliki keinginan untuk merubah diri dalam pembelajaran.

2) Rendahnya keterampilan membaca literatur

Sejarah tidak lepas dari narasi-narasi yang harus dibaca dan dipahami oleh masyarakat. Seperti yang diungkapkan Garvey \& Krug (dalam Isjoni, 2007:91) bahwa pembelajaran sejarah merupakan pengembangan potensi siswa yaitu menulis, mendramatisasikan, serta kemampuan kreatif lainnya (kemampuan mengkomunikasikan pengetahuan dan pemahaman sejarah). Sedangkan salah satu tujuan pendidikan sejarah yang tidak lepas dari literatur yaitu mengembangkan kemampuan mencari, mengolah, mengemas, dan mengkomunikasikan informasi (Hasan, 2012:7). Dengan demikian, potensi tersebut tidak bisa melepaskan diri untuk membaca literatur.

Pada PTK ini, siswa dipaksakan untuk terus membaca literatur selama enam kali tindakan. hal ini mengacu kepada Schmidt (1991) bahwa keterampilan yaitu "merupakan kemampuan untuk membuat hasil akhir dengan kepastian yang maksimum dan pengeluaran energy dan waktu yang minimum". Singer (1980) menambahkan bahwa "keterampilan adalah derajat keberhasilan yang konsisten dalam mencapai suatu tujuan dengan efisien dan efektif'. Dengan demikian, keterampilan berpikir kesejarahan harus dicapai melalui beberapa tindakan. H.W Johnson (dalam Singer, 1980) menyatakan bahwa keteram- 
pilan harus juga adaptif yaitu cakap meskipun di bawah kondisi yang berbedabeda. Hal ini ditunjukan dengan beberapa kali tindakan yang dilakukan pada PTK ini dengan desain yang berbeda-beda setiap tindakannya.

3) Keterbatasan Referensi Biografi Tokoh R.A Lasminingrat

Keterbatasan referensi dalam pembelajaran tokoh lokal menjadi kendala, seperti penelitian Desi Hilda Sari (2011) mengenai Biografi Siti Manggopoh. Begitupun referensi biografi R.A Lasminingrat secara penerbitan masih kurang. Hal ini hanya ditemukan dua penulis yaitu Nina Herlina Lubis yang merupakan seorang sejarawan UNPAD dan Dedi Effendie yang secara otodidak menulis sejarah, walaupun telah mengikuti kursus sejarah. Buku tersebutpun masih sulit didapatkan karena tidak dijual secara komersial.

Pembelajaran sejarah lokal merupakan hal penting untuk memberikan identitas kepada siswa tentang sejarah lokalnya. Seperti hasil penelitian Desi Hilda Sari (2011) yang menemukan pemakaian biografi local meningkatkan motivasi siswa dan menjadi teladan bagi siswa. Penelitian Eha Julaeha (2012) menemukan bahwa dengan pembelajaran peneladanan biografi pahlawan memberikan kontribusi positif terhadap peserta didik dengan meningkatnya karakter budaya. Radjilun (2011), pembelajaran berbasis biografis mampu mewujudkan kesadaran dalam bentuk positif menjaga kelanggengan hubungan social siswa dan guru untuk menjaga integrasi bangsa.

Begitupula dengan biografi, Warren (dalam Hasan, 2012:57) menyatakan bahwa pendidikan sejarah menjadi kaya melalui pendekatan pengajaran biografi karena dapat membuat pendidikan sejarah menjadi memiliki kedalaman, menjadi "bank of examples" untuk "courage, determination, honesty, willingness to work.

Biografi menjadi penting kalau merujuk kepada teori belajar Albert Bandura. Proses pembelajaran akan efektif melalui pembelajaran observasional atau dinamakan dengan imitasi/modeling. Pembelajaran observasional yaitu pembelajaran yang dilakukan ketika seseorang mengamati dan meniru perilaku orang lain (Santrock, 2007:287300). Pembelajaran biografi melalui sebuah referensi narasi sejarah diharapkan mampu memotivasi siswa sehingga keterampilan berpikir kesejarahanpun tercapai.

Pada PTK ini sebagai alternative keterbatasan referensi tersebut, guru mitra dan guru peneliti menentukan artikel yang berhubungan R.A Lasminingrat. Sehingga, siswa melalui materi sejarah biografi R.A Lasminingrat mampu melakukan pembelajaran keterampilan berpikir kesejarahan sesuai dengan indikator yang disepakati.

\section{PENUTUP}

Berdasarkan uraian hasil penelitian, maka dapat disimpulkan bahwa: pertama, desain pembelajaran diperlukan untuk mengetahui keterampilan berpikir kesejarahan siswa. Langkah awal yaitu mendesain pembelajaran melalui RPP yang mampu meningkatkan keterampilan-keterampilan yang ingin dicapai. Keterampilan ini dilakukan melalui RPP dengan tiga tindakan untuk mengenai kemampuan chronological thinking, historical comprehenship, dan historical research capabilities pada Siklus I. Siklus II mengenai kemampuan historical analysis and interpretation dan historical issues-analysis and decision making. Desain yang diperlukan oleh guru yaitu harus tetap terpokus pada pengelolaan model, strategi 
dan penilaian. Melalui model text book study, strategi pembelajaran langsung (directive) dan penilaian asesmen alternatif berupa task mengefektifkan pembelajaran keterampilan berpikir kesejarahan.

Kedua, penerapan pengembangan keterampilan berpikir kesejarahan siswa dalam pembelajaran sejarah melalui penggunaan biografi tokoh R.A Lasminingrat sebagai sumber pembelajaran sejarah terjadi peningkatan. Penerapan ini melalui pembiasaan membaca terhadap narasi sejarah yang diberikan. Hasil dari pembiasaan tersebut yaitu terlihat hasil yang memuaskan dari task yang diberikan oleh guru. Task tersebut digunakan sebagai tindakan guru melalui siklus perencanaan, observasi, dan refleksi.

Ketiga, kendala-kendala yang dihadapi oleh guru dalam pembelajaran keterampilan berpikir kesejarahan melalui penggunaan sumber sejarah R.A Lasminingrat yaitu pertama, tingkat kompleksitas dan triablitas mengenai penerapan keterampilan berpikir kesejarahan siswa melalui biografi tokoh R.A Lasminingrat masih tinggi dan uji coba memerlukan pengulangan-pengulangan. $\mathrm{Ke}$ $d u a$, rendahnya motivasi dan keterampilan membaca literature yang merupakan dasar dalam keterampilan berpikir kesejarahan yang bersifat narasi sejarah. Ketiga, keterbatasan mengenai referensi biografi R.A Lasminingrat yang merupakan bahan materi dalam pembelajaran keterampilan berpikir kesejarahan siswa.

\section{DAFTAR PUSTAKA}

Effendie, D (2011) Raden Ajoe Lasminingrat 1843-1948; Perempuan Intelektual Pertama di Indonesia, Garut: CV Studio Proklamasi

Hasan, S H, (2012). Pendidikan Sejarah Indonesia: Isu dalam Ide dan Pembelajaran, Bandung : Rizqi Press
Hariyono, (1995). Mempelajari Sejarah Secara Efektif, Jakarta : Pustaka Jaya Isjoni (2007) Pembelajaran Sejarah Pada Satuan Pendidikan, Bandung : Alfabeta Julaeha, E (2012) Pengaruh Pembelajaran Sejarah Dengan Peneladanan Biografi Pahlawan Terhadap Pengembangan Karakter Siswa (Studi Kuasi Eksperimen terhadap Siswa Kelas XI IPS di SMAN 8 Bandung), (Tesis) Sekolah Pascasarjana, Universitas Pendidikan Indonesia, Bandung

Kartodirdjo, S, (1993). Pendekatan Ilmu Sosial Dalam Metodologi Sejarah, Jakarta : PT Gramedia Pustaka Utama

Lubis, N H (2009) Kajian Tentang Perjuangan Raden Аyu Lasminingrat Dalam Rangka Pengusulannya sebagai Pahlawan Nasional, Bandung : Pusat Penelitian Kemasyarakatan dan Kebudayaan Lembaga Penelitian Universitas Padjajaran

Mulyana, A \& Gunawan, R, Ed, (2007). Sejarah Lokal Penulisan dan Pembelajaran di Sekolah, Bandung : Salamina Press

Murni (2006) Model Pembelajaran Holistik dalam Pengembangan Keterampilan Berpikir Kesejarahan. (Disertasi). Sekolah Pascasarjana, Universitas Pendidikan Indonesia, Bandung

Muslich, M (2011) Authentic Assessment : Penilaian Berbasis Kelas dan Kompetensi, Bandung : PT Refika Aditama

Ma'mur, T, (2008). “Upaya meningkatkan kualitas pembelajaran sejarah melalui Historical Thinking", dalam Sejarah dalam Keberagaman Penghormatan Kepada Prof. Helius Sjamsuddin,Ph.D., $M A$, Bandung : Jurusan Pendidikan Sejarah FPIPS UPI

Radjilun, M. S (2011) Implementasi Pembelajaran Berbasis Biografis: Nilai-Nilai Kejuangan Sultan Baabullah Dalam Membangun Patriotisme Dan Nasionalisme Siswa (Studi Inquiri Kualitatif Pembelajaran IPS Sejarah di SMA Negeri 3 Ternate), (Tesis) Sekolah 
Pascasarjana, Universitas Pendidikan Indonesia, Bandung

Santrock, J. W, (2007). Psikologi Pendidikan , Jakarta: Kencana Prenada Media Group

Sari, D. H (2011) Biografi Siti Manggopoh Sebagai Sumber Kearifan Lokal Untuk Meningkatkan Motivasi Belajar Siswa Dalam Pembelajaran IPS (Studi Kasus Pada Siswa MAN Koto Kecil Kabupaten Agam Propinsi Sumatera Barat), (Tesis) Sekolah Pascasarjana, Universitas Pendidikan Indonesia, Bandung

Schmidt, R A (1991) Motor Learning and Performance: From Principle into Practice. Human Kinetics. Champain. IL

Singer, R N (1980) Motor Learning and Human Performance: An Application to Motor Skills and Movement Behaviours. Macmilan Pub. New York.

Soebadio, H (1979) Peranan Kartini Untuk Masa Depan. Dalam Bunga Rampai Karangan Mengenai Kartini;; Satu Abad Kartini 1879-1979, Jakarta : Sinar Harapan

Suprijono, A (2013) Cooperative Learning Teori \& Aplikasi PAIKEM. Yogyakarta: Pustaka Pelajar

Surya, M (2004) Psikologi Pembelajaran \& Pengajaran, Bandung : Pustaka Bani Quraisy

Wiriaatmadja, R (2012) Metode Penelitian Tindakan Kelas Untuk Meningkatkan Kinerja Guru dan Dosen, Bandung : Remaja Rosdakarya.

Zainul, A (2001) Alternative assessment, Jakarta : PAU-PPAI, Universitas Terbuka

\section{Sumber Internet :}

Lasminingrat, Perempuan Hebat dari Garut (Resensi Buku dari Kajian Tentang Perjuangan Raden Ayu Lasminingrat) [online] tersedia di http://nosferatubook.blogspot.com/2010 /11/lasminingrat-perempuan-hebat-darigarut.html diakses tanggal 23 Nopember 2013.
Standards,

Historical Thinking

http://www.nchs.ucla.edu/Standards/ diunduh tanggal 23 Nopember 2013. R.A Lasminingrat Unsur Pers Miliki Andil Tenggelamkan Ketokohan Lasminingrat, [Online] tersedia di http://smk30jakarta.net/ind/index2.php? option=com_content $\& d o \_p d f=1 \&$ id $=28$ $\underline{0}$ diakses tanggal 08 Oktober 2013

Hutari, F (2009) " $R A$ Lasminingrat, Tokoh Perempuan Intelektual Pertama", dalam "Kompas " tanggal 19 Desember 2009, [online] tersedia di http://www.goodreads.com/topic/show/ 258705-perempuan-intelektual-pertamaindonesia diakses tanggal 13 Januari 2014

Kamsori, E (2006) "Meningkatkan Minat dan Prestasi Mahasiswa pada Mata Kuliah Sejarah Amerika dengan Menggunakan Historical Thinking". Jurnal Pendidikan Ilmu Sosial. XIV, hlm 26

Mahendra, A (TT) "Modul Perkembangan Belajar Motorik", [online] tersedia di http://file.upi.edu/Direktori/FPOK/JUR. _PEND._OLAHRAGA/1963082419890 $31-$

AGUS_MAHENDRA/Modul_Perkemb angan \%26 Belajar Motorik Agus M ahendra/Modul_7-

Keterampilan dan Taksonomi Gerak. pdf diakses tanggal 3 Juni 2014

Sastrawiguna, O (TT) Sejarah Singkat dan Biografi R.A Lasminingrat, [online] tersedia di http://www.inilahgarut.com/tokohgarut/sejarah-singkat-dan-biografi-ralasminingrat.html diakses tanggal 08 Oktober 2013.

Sjamsuddin, H (1999). Sejarah dan Pendidikan Sejarah. Mimbar Pendidikan XVII.

Yudono, J (TT) Buku Karangan Lasminingrat "Nyangkut" di Canberra, [Online] tersedia di http://www.garutkab.go.id/download_fil es/article/Lasminingrat.pdf diakses tanggal 08 Oktober 2013 
